Abstracta Iranica Abstracta Iranica

Revue bibliographique pour le domaine irano-aryen

Volume 28 | 2007

Comptes rendus des publications de 2005

\title{
La médecine spirituelle. Présentation et traduction par Rémi Brague, Paris, GF Flammarion, 2003, 206 p.
}

\section{Pierre Lory}

\section{(2) OpenEdition} Journals

Édition électronique

URL : http://journals.openedition.org/abstractairanica/13512

DOI : 10.4000/abstractairanica. 13512

ISSN : 1961-960X

Éditeur :

CNRS (UMR 7528 Mondes iraniens et indiens), Éditions de l'IFRI

\section{Édition imprimée}

Date de publication : 15 mai 2007

ISSN : 0240-8910

Référence électronique

Pierre Lory, "La médecine spirituelle. Présentation et traduction par Rémi Brague, Paris, GF

Flammarion, 2003, 206 p. », Abstracta Iranica [En ligne], Volume 28 | 2007, document 304, mis en ligne le 18 septembre 2007, consulté le 25 septembre 2020. URL : http://journals.openedition.org/ abstractairanica/13512 ; DOI : https://doi.org/10.4000/abstractairanica.13512

Ce document a été généré automatiquement le 25 septembre 2020.

Tous droits réservés 


\title{
La médecine spirituelle. Présentation et traduction par Rémi Brague, Paris, GF Flammarion, 2003, 206 p.
}

\author{
Pierre Lory
}

Dans cet ouvrage, R. Brague nous offre la traduction complète du Țebb al-rūhānī du grand médecin iranien Muhammad ibn Zakariyyā al-Rāzī, le Rhazès du Moyen Age latin. Il s'agit d'un des rares textes de philosophie qui nous soit resté de l'esprit fort et original que fut Rhazès. Nous avons affaire à un traité de morale, dissertant sur les bienfaits des grandes vertus et les dangers des divers vices. Le ton n'est guère islamique, il évoque plutôt la sagesse grecque, épicurienne notamment. La traduction de R.B., très claire, précise et étayée de notes, est précédée de 50 pages d'introduction présentant le temps, le milieu et la pensée assez controversée, anti-prophétique de Rāzī. Un ouvrage fort utile bien sûr pour présenter la pensée médiévale orientale dans sa diversité.

INDEX

Thèmes : 9. Philosophie

\section{AUTEURS}

PIERRE LORY

EPHE - Paris 